\title{
KEPUASAN STAKEHOLDERS TERHADAP LULUSAN PRODI KI/ MPI FAKULTAS TARBIYAH DAN KEGURUAN UIN ALAUDDIN MAKASSAR
}

\author{
A. ACHRUH, ILYAS ISMAIL, RIDWAN IDRIS \\ Fakultas Tarbiyah dan Keguruan UIN Alauddin Makassar \\ Email: andiachruh@gmail.com, daengilyas12@gmail.com, ridwan.idris@uin- \\ alauddin.ac.id \\ (Article History) \\ Received November 19, 2020; Revised December 17, 2020; Accepted December 20, 2020
}

\begin{abstract}
:
This study will discuss stakeholder's satisfaction with the performance of $\mathrm{KI} / \mathrm{MPI}$ graduates at the Tarbiyah and Teaching Faculty of UIN Alauddin Makassar. Then try to find out the criteria that stakeholders want. This research is quantitative descriptive. The population of this study were MPI program graduates who were in the district. Jeneponto, Kab. Selayar, Kab. Pinrang, Makassar City, Kab. Barru, and the City of Parepare. The technique used was a questionnaire with a Likert scale instrument. The analysis used is descriptive quantitative. The criteria that the stakeholders want for graduates of the Islamic Education Management Study Program (MPI), Faculty of Tarbiyah and Teacher Training, UIN Alauddin Makassar are: (1) responsibility; (2) productive;

(3) target orientation or results; (4) high motivation; (5) patient and work hard;

(6) think and act positively; and (7) maintain relationships with peers.
\end{abstract}

Keywords: Satisfaction, Graduates, KI/MPI

\section{PENDAHULUAN}

rogram Studi (Prodi) Manajemen Pendidikan Islam (MPI) telah mengalami berbagai macam perubahan dan juga perkembangan sejak awal berdirinya pada tahun 1994. Pasang surut dalam penerimaan mahasiswa pada Prodi MPI telah dialami dengan berbagai dinamikanya. Pada awal berdirinya, MPI/KI berhasil menerima mahasiswa lebih dari 100 orang, namun pada tahun selanjutnya menurun seiring banyaknya persaingan dengan institusi lain. Ketika IAIN Alauddin berubah menjadi UIN Alauddin, maka Prodi MPI berhasil berkembang dan mendapat peminat yang lumayan besar. Pada tahun 2017/2018 menerima mahasiswa sebanyak 82 orang dengan peminat mencapai 600 orang.

Prodi MPI dapat dikatakan sebagai program studi yang cukup disegani dan mendapat tempat di hati masyarakat terutama dalam pengembangan serta peningkatan mutu organisasi pendidikan Islam. Prodi MPI juga bisa dikatakan cukup prestisius dan sangat prospektif untuk digunakan di dunia kerja. Prodi MPI dibangun untuk dapat menjadi pengelola organisasi keislaman yang dikelola secara profesional dan bermutu. Akan tetapi pada kenyataannya, seiring berjalan waktu terdapat banyak hambatan dan rintangan yang membuat perkembangan Prodi MPI 
tidak berjalan dengan mulus. Salah satu hal yang menjadi hambatan adalah masyarakat tidak terlalu mengenal baik Prodi MPI. Kebanyakan masyarakat dan lembaga-lembaga terkait tidak terlalu memahami tujuan berdirinya MPI apalagi kompetensi yang dimilikinya. Hal ini berdampak pada pemahaman masyarakat menganggap alumni MPI disamakan dengan guru. Hambatan yang lain adalah, Prodi MPI belum banyak memiliki kerjasama dengan berbagai pihak, baik pemerintah maupun dunia usaha dan dunia industri.

Selain hambatan di atas, Prodi MPI juga memiliki kelemahan terutama pada alumni yang belum terkoordinir dengan baik. Pelacakan alumni (tracer study) belum dilakukan secara rutin membuat alumni sangat sulit dilibatkan dalam setiap kegiatan yang dilakukan prodi. Abdi dan Ananiah mengemukakan bahwa dalam memetakan peluang sebagai bagian pengembangan prodi, perlu dilakukan hal-hal berikut; (1) menjalin kerjasama dengan berbagai pihak, baik dari lembaga pemerintah maupun dari lembaga swasta, yang mungkin saja selama ini belum digarap; (2) memetakan lapangan kerja bagi lulusan, seperti guru agama, konsultan dan trainer pendidikan, dan lain-lain (Abdi dan Ananiah, 2013).

Lulusan dari Prodi MPI berada dan menyebar ke beberapa daerah baik daerah yang berada di Sulawesi Selatan maupun di luar Sulawesi Selatan. Profesi yang ditekuni kebanyakan di bidang pendidikan, baik itu menjadi guru, administrator sekolah, dan juga dosen. Selain itu, ada juga berprofesi sebagai pengusaha, dengan berbagai macam bidangnya seperti di bidang kuliner, industri kreatif dan lain-lain. Lulusan MPI juga berada pada berbagai lembaga, baik lembaga pemerintahan maupun swasta, dan ada juga sebagai pekerja sosial kemasyarakatan.

Pengguna alumni Prodi MPI, mempunyai dua hal yang berbeda, ada yang puas ada pula yang mungkin saja tidak puas. Pengguna yang puas ketika alumni yang dipakai mempunyai kinerja yang baik, sebaliknya pengguna yang tidak puas karena alumni yang bekerja di lembaganya tidak memiliki kinerja bahkan mungkin tidak memiliki pengetahuan dan keterampilan yang dibutuhkan. Pengetahuan dan keterampilan yang digunakan dalam lembaga-lembaga tersebut, sedikit banyaknya dari Prodi MPI yang menjadi almamater sebelumnya. Dengan demikian Prodi MPI perlu selalu melakukan perbaikan dan pengembangan agar nantinya jika terdapat kekurangan dan kelemahan bisa segera diatasi.

Membahas kepuasan pelanggan, tidak akan terlepas dari yang namanya kualitas. Produk atau layanan yang memberi kepuasan tentu saja berasal dari kualitas. Maka tidak salah kalau konsep dari Total Quality Management (TQM) sangat tergantung pada kepuasan pelanggan. Demikian pula ketika berbicara dalam layanan (service). Ketika konsep ini dihubungkan dengan penelitian ini, maka kepuasan pengguna pada lulusan yang digunakan berarti Prodi yang mengeluarkan juga berkualitas.

Wayhof dalam Lavelock mendefinisikan; "quality is the degree of excellent intended, and control of variability in achieving that excellence, in meeting the 


\section{A. ACHRUH, ILYAS ISMAIL, RIDWAN IDRIS}

customer's requirements" (Lavelock, 1988). Pernyataan di atas, mengindikasikan bahwa makna sebuah kualitas tergantung pada pelanggan. Artinya jika ingin mengetahui produk atau layanan itu berkualitas tanyalah pada pengguna.

Kepuasan atau satisfaction berasal dari bahasa Latin yaitu satis yang berarti cukup atau sudah memadai, kemudian facio yang berarti membuat atau melakukan. Kepuasan bisa diartikan sebagai "upaya pemenuhan sesuatu" atau "membuat sesuatu memadai" (Sarjono, 2007: 13-14). Puas adalah kata awal dari kepuasan yang bisa dimaknai sebagai merasa senang, merasa lega, dan juga kenyang. Bisa juga dimaknai dengan sudah merasai secukup-cukupnya atau sudah terpenuhi hasrat hatinya. Kepuasan pengguna adalah sikap positif pengguna lulusan terhadap Iuaran pendidikan tinggi karena adanya kesesuaian antara harapan dari pelayanan dibandingkan dengan kenyataan yang diterimanya (Sopiatin, 2010: 33).

Sugito menggambarkan kepuasan sebagai keadaan terpenuhinya suatu keinginan, harapan, dan kebutuhan pengguna (dalam Srinadi, 2008: 217). Sementara Supranto menggambarkan Kepuasan adalah tingkat perasaan seseorang setelah membandingkan kinerja/hasil yang dirasakannya dengan harapannya (Supranto, 2011: 233).

Mengacu pada definisi-definisi tersebut di atas, maka dapat disimpulkan bahwa kepuasan pengguna berarti perasaan senang, puas dan kelegaan terhadap kinerja lulusan perguruan tinggi yang sementara bekerja di lembaganya.

Terdapat lima indikator dari kepuasan yang dikemukakan oleh Berry dan Parasuraman yang berkaitan dengan mutu Iulusan Prodi, yaitu:

\section{Integritas}

Integritas bisa diartikan dengan kejujuran, tapi lebih luas pengertiannya sampai pada kemampuan seseorang dalam tanggung jawab. Kejujuran yang bertanggung jawab berarti kemampuan untuk menghindari tindakan koruptif dalam bekerja. Kreativitas dan keikhlasan menjadi kunci pada integritas ini. Lulusan yang berintegritas akan menghasilkan produktivitas kerja yang baik dan dapat mengembangkan kemampuannya untuk kepentingan lembaga dan masyarakat.

\section{Profesionalisme}

Profesionalisme terkait dengan pelaksanaan tugas pokok dan fungsinya secara baik dan benar. Profesionalisme juga diartikan dengan memegang komitmen untuk berkerja dengan baik, sehingga bisa melahirkan produk dan layanan terbaik.

\section{Penguasaan Bahasa Asing}

Penguasaan bahasa asing merupakan kemampuan dalam berkomunikasi aktif menggunakan bahasa selain bahasa Indonesia. Kemampuan ini menjadi penting mengingat organisasi harus memiliki kerjasama dengan berbagai komunitas baik di dalam maupun di luar negeri. Oleh karena itu, setiap lulusan sangat perlu menguasai kemampuan bahasa asing sehingga dapat lebih bermanfaat di dalam organisasinya. 


\section{Keterampilan IT}

Keterampilan IT juga merupakan kemampuan yang wajib dimiliki. Hal ini penting mengingat perkembangan teknologi sangat cepat dan harus dibarengi dengan kemampuan organisasi untuk mengejarnya. Kemampuan IT berarti kemampuan menggunakan, memanfaatkan, dan mengembangkan Informasi Teknologi baik di bagian hardware maupun software.

\section{Keterampilan Berkomunikasi}

Kemampuan berkomunikasi berarti kemampuan atau keahlian dalam mengungkapkan pemikiran, keingingan, perasaan, baik dengan komunikasi verbal maupun non-verbal untuk mendapatkan perhatian orang lain. Organisasi akan terus berkomunikasi dengan banyak orang, maka seharusnya semua anggota organisasi memiliki kemampuan ini.

\section{Kemampuan Teamwork}

Kemampuan Teamwork adalah kemampuan untuk menjadi bagian dalam sebuah kelompok untuk melakukan pekerjaan secara bersama-sama dengan sikap yang kooperatif. Hal ini mengindikasikan bahwa seseorang dalam organisasi harus bersedia untuk bekerja dengan orang lain dan bekerja bersama orang lain. Kemampuan ini berarti kemampuan kerjasama sebagai anggota kelompok bukan sebagai pemimpin kelompok.

\section{Kemampuan Beradaptasi}

Kemampuan beradaptasi berarti kemampuan untuk menyesuaikan diri dengan lingkungan kerja dengan kondisi yang mungkin saja berubah-ubah. Lulusan prodi harus memiliki ini agar supaya dapat hidup dan bekerja di manapun berada. Kemampuan ini penting karena akan membuat lulusan menjadi survive dan mempengaruhi orang lain secara baik.

Dari pendahuluan di atas, maka peneliti dapat merumuskan dua masalah pokok yaitu; bagaimana tingkat kepuasan pengguna terhadap alumni KI/MPI?, dan kriteria apa yang mereka inginkan?

\section{METODE PENELITIAN}

Penelitian ini adalah penelitian deskriptif kuantitatif yang dapat diartikan sebagai penelitian yang berpusat atau menghasilkan angka-angka atau data deskriptif. Sesuai dengan judul penelitian, maka penelitian berada pada wilayah Sulawesi Selatan. Teknik yang digunakan adalah angket yang berisi sejumlah penyataan yang terkait dengan indikator. Instrumen yang dipakai pada penelitian ini adalah skala likert. Adapun analisis deskriptif yang digunakan adalah analisis deskriptif kuantitatif.

\section{HASIL PENELITIAN DAN PEMBAHASAN}

Penelitian ini adalah penelitian deskriptif dengan menggunakan metode survey. Data-data atau indikator yang akan diambil sebagai hasil penelitian meliputi: 


\section{A. ACHRUH, ILYAS ISMAIL, RIDWAN IDRIS}

integritas, profesionalisme, kemampuan bahasa Inggris, penggunaan Teknologi Informasi ( $\mathrm{TI}$ ), kemampuan berkomunikasi, kerjasama tim, dan pengembangan diri. Selain itu, hasil penelitian ini juga mendapatkan data tentang kriteria yang diinginkan oleh stakeholders pada Iulusan Prodi Manajemen Pendidikan Islam (MPI) Fakultas Tarbiyah dan Keguruan UIN Alauddin Makassar. Untuk lebih jelasnya hasil penelitian ini dapat dipaparkan secara jelas sebagai berikut:

\section{Kepuasan Pengguna (Stakeholders) terhadap Lulusan Prodi Kependidikan Islam (KI)/Manajemen Pendidikan Islam (MPI)}

Untuk menjawab permasalahan ini, ada empat hal yang menjadi indikator dari variabel ini, yaitu: (1) integritas; (2) profesionalisme; (3) kemampuan bahasa Inggris; (4) penggunaan TI; (5) kemampuan berkomunikasi; (6) kerjasama tim; dan (7) pengembangan diri. Hasil penelitian menunjukkan hal-hal sebagai berikut:

\section{Integritas}

Untuk menilai integritas, peneliti meninjau beberapa sub indikator yaitu: kejujuran, kedisiplinan, motivasi dan etos kerja. Hasil penelitian menunjukkan bahwa 97\% responden menilai alumni MPI yang bekerja pada instansi masingmasing lembaga sangat baik pada indikator ini. Artinya bahwa alumni telah menerapkan nilai seperti kejujuran, kedisiplinan, motivasi, dan etos kerja sangatlah baik. Hasil ini juga mengandung makna bahwa apa yang telah dilakukan Prodi MPI selama ini untuk membina integritas mahasiswa sudah baik.

Hasil di atas menunjukkan bahwa nilai-nilai keislaman dalam membentuk karakter alumni selama mereka kuliah telah menunjukkan hasil yang positif. Nilainilai seperti kejujuran, kedisiplinan, motivasi, dan etos kerja telah mereka dapatkan di pembelajaran dan mampu terbawa ketika mereka berada di tengah masyarakat.

\section{Profesionalisme}

Untuk menilai profesionalisme, peneliti meninjau pada enam aspek, yaitu: kemampuan menerapkan keahlian atau ilmu pengetahuan mereka, produktivitas kerja, inovasi, kemampuan menyelesaikan masalah, kemampuan beradaptasi, dan tanggap terhadap kebutuhan pasar.

Hasil penelitian menunjukkan bahwa $83 \%$ responden menilai Sangat Baik. Berdasarkan hasil di atas dapat dimaknai bahwa profesionalisme di kalangan alumni MPI sudah sangat bagus, walaupun perlu ada peningkatan, di mana ada 5\% responden yang masih menilai cukup. Artinya nilai ini meskipun kecil tapi perlu ada penanganan yang lebih serius, sehingga di kemudian hari bisa teratasi.

Hasil di atas menunjukkan bahwa tingkat profesionalisme dari alumni MPI yang telah bekerja sangat menggembirakan artinya bahwa kemampuan menerapkan keahlian atau ilmu pengetahuan mereka, produktivitas kerja, inovasi, kemampuan menyelesaikan masalah, kemampuan beradaptasi, dan tanggap terhadap kebutuhan pasar sudah dapat diterapkan dalam lingkungan kerja mereka. Alumni MPI mampu mengelola dengan baik apa yang telah didapatkan di perkuliahan. 
Kurikulum yang telah diterapkan selama ini akan terus dipertahankan dengan meningkatkan sisi yang lain yang dianggap masih kurang. Hal ini diperlukan mengingat masih ada sekitar $20 \%$ responden yang menyatakan belum puas atas profesionalisme almni.

\section{Kemampuan Bahasa Inggris}

Untuk mendapatkan hasil dari aspek ini peneliti mengukurnya melalui kemampuan menggunakan dan menerjemahkan bahasa Inggris sehari-hari atau yang biasa digunakan dalam lingkungan kerja.

Hasil penelitian menunjukkan bahwa $80 \%$ responden menilai alumni mampu menggunakan bahasa Inggris dengan Sangat Baik. Hasil ini menunjukkan hal yang cukup memuaskan.

Berdasarkan hasil tersebut dapat dilihat bahwa dalam menggunakan bahasa Inggris alumni MPI telah menunjukkan kemampuan yang cukup baik. Artinya bahwa pengembangan kurikulum yang di dalamnya terdapat mata kuliah bahasa Inggris telah menunjukkan hasil yang baik.

Meskipun dalam proses selanjutnya pihak Prodi MPI akan terus mengembangkan kemampuan bahasa Inggris ini dengan mengusahakan berbagai pelatihan bahasa Inggris. Bukan hanya pada bahasa Inggris percakapan, akan tetapi juga dalam pengembangan bahasa Inggris yang lebih akademik.

Kemampuan dalam berbahasa Inggris memang sangat diperlukan karena dengan kemampuan ini memang menjadi syarat mutlak dalam berkompetisi di lingkungan kerja dan juga di lingkungan akademik.

\section{Penggunaan Teknologi Informasi}

Untuk menilai pada aspek ini, peneliti mengukurnya berdasarkan pada indikator kecakapan dalam menggunakan Teknologi Informasi (TI), kemampuan mengoperasikan segala alat TI, penggunaan TI dalam lingkungan kerja.

Hasil penelitian pada aspek ini menunjukkan bahwa $85 \%$ responden menilai bahwa penggunaan TI di kalangan alumni yang bekerja Sangat Baik.

Hasil di atas menunjukkan bahwa sebagian besar stakeholders menilai alumni MPI yang bekerja di lembaganya mampu menggunakan $\mathrm{TI}$ dengan sangat baik. Artinya bahwa dalam bekerja sebagian besar alumni MPI cakap menggunakan TI dan memanfaatkannya dalam mengerjakan setiap tugas-tugas yang diberikan.

Hasil di atas juga menunjukkan bahwa program pembelajaran TI di lingkungan Prodi MPI sudah sangat baik. Prodi MPI telah melengkapi fasilitas pembelajaran berbasis E-learning. Selain itu fasilitas fisik berupa pemasangan hotspot di Fakultas Tarbiyah dan Keguruan serta Manajemen Pendidikan Islam (MPI) juga telah dilakukan untuk membantu mahasiswa mengakses E-learning melalui internet.

Tingginya penilaian sangat baik oleh pihak pengguna lulusan dimungkinkan karena alumni telah menguasai dan sekaligus memanfaatkan seluruh kemampuan dan potensi teknologi informasi ke dalam keseharian mereka untuk meningkatkan 


\section{A. ACHRUH, ILYAS ISMAIL, RIDWAN IDRIS}

kinerja. Penggunaan teknologi informasi ini terus digalakkan terutama dalam mengakses jurnal berkualitas yang tersedia secara online.

\section{Kemampuan Berkomunikasi}

Untuk menilai pada aspek ini, peneliti menggunakan indikator kemampuan menggunakan bahasa asing dalam mengemukakan pendapat atau idenya dan kemampuan menggunakan bahasa yang santun dalam berkomunikasi.

Hasil penelitian menunjukkan bahwa $87 \%$ responden menilai kemampuan berkomunikasi alumni MPI Sangat Baik. Hasil tersebut mengindikasikan bahwa alumni MPI ketika berada di lingkungan kerja telah menunjukkan kemampuan bahasa asing mereka, baik Arab maupun Inggris, dengan sangat baik. Selain itu mereka juga telah menunjukkan kesantunan dalam bertutur kata dan juga berkomunikasi. Hasil ini tentu saja sangat membanggakan. Meski demikian perlu ada pengembangan yang lebih baik lagi dengan harapan sisa dari $87 \%$ tersebut juga bisa menjadi lebih baik.

Berdasarkan hasil tersebut juga mengindikasikan bahwa selama ini program atau kurikulum yang dibangun di Prodi MPI khususnya dalam meningkatkan kemampuan komunikasi sudah bisa diterima dan cukup untuk dapat memberikan kemampuan atau skill yang memadai.

Sesuai yang telah diutarakan sebelumnya bahwa program di Prodi MPI dalam meningkatkan kemampuan berkomunikasi calon alumni telah dapat dilihat dan dinyatakan sangat baik. Dengan demikian akan tetap dipertahankan dengan tetap menerapkan kemampuan ini pada mata kuliah seperti Manajemen Kewirausahaan, Manajemen Strategik, dan Praktek Pengalaman Lapangan (PPL). Selain itu akan ditambah dengan program atau kegiatan-kegiatan lain di luar perkuliahan seperti pelatihan atau pendidikan singkat.

\section{Kerjasama Tim}

Untuk menilai aspek kerjasama tim, peneliti menggunakan dua indikator yaitu; kemampuan manajerial dan kemampuan motivator kerja.

Hasil penelitian menunjukkan bahwa 94\% responden menilai bahwa kerjasama tim alumni MPI di lingkungan kerjanya Sangat Baik. Hasil ini menunjukkan bahwa para pengguna lulusan MPI sangat puas terhadap kerjasama tim yang telah ditunjukkan oleh alumni MPI di lembaga yang ditempati bekerja.

Berdasarkan hasil di atas, menunjukkan para pengguna lulusan MPI merasakan adanya kerjasama tim yang baik dari lulusan yang mereka gunakan di lingkungan kerja. Hasil ini juga mengindikasikan bahwa program perkuliahan selama ini telah memberikan kemampuan dalam melakukan kerjasama tim yang baik.

Tingginya penilaian sangat baik terhadap kompetensi ini dimungkinkan karena alumni memiliki komitmen yang tinggi pada pekerjaannya, sehingga selalu menjaga kekompakan dengan teman sejawat untuk totalitas tim. Kerjasama yang baik didukung adanya rasa saling percaya, ketulusan, saling memahami, dan toleransi. Kerjasama tim juga selalu dikembangkan dalam kegiatan kurikuler maupun 
ekstrakurikuler mahasiswa. Hal ini dapat dilihat dengan pemberian tugas/project kelompok untuk melatih kerjasama mereka. Selain itu, pada proses pembelajaran dosen ditekankan untuk menerapkan model pembelajaran kooperatif.

\section{Pengembangan Diri}

Untuk mengukur aspek ini, peneliti menggunakan dua indikator yaitu; kesiapan dalam mengembangkan potensinya dan upaya alumni dalam mengembangkan kemampuan dan potensi tersebut setiap saat.

Hasil penelitian menunjukkan $86 \%$ responden menilai pengembangan diri alumni Sangat Baik. Hal ini mengindikasikan bahwa alumni MPI sebagian besar memiliki kesiapan dalam mengembangkan potensinya dan juga mereka memiliki upaya yang sangat besar dalam pengembangan potensi tersebut.

Hasil di atas menunjukkan bahwa program pengembangan diri pada Prodi MPI telah berjalan dengan baik dan menghasilkan sesuatu yang baik. Program yang dimaksud adalah proses pengembangan diri yang termaktub dalam perkuliahan dan juga di luar perkuliahan.

Di dalam program perkuliahan dapat dilihat pada pendekatan, metode, model, dan teknik yang digunakan oleh dosen. Di mana proses perkuliahan dengan pendekatan saintifik dan kooperatif telah memberikan hasil yang baik. Demikian juga pada model pembelajaran yang variatif yang selalu berubah tergantung pada kondisi dan situasi perkuliahan. Selain itu, pertimbangan lain adalah karakteristik dari peserta didik di mana setiap kelas memiliki karakter yang berbeda.

Dari hasil penelitian ini, Prodi Manajemen Pendidikan Islam (MPI) akan menindaklanjuti aspek-aspek kompetensi yang perlu segera dibenahi agar dapat meningkatkan kualitas pembelajaran untuk menghasilkan Iulusan/alumni yang berdaya saing tinggi dan mempertahankan aspek yang telah memenuhi kepuasan pengguna/user. Proses perbaikan kompetensi calon lulusan ini akan dilakukan dengan mengintensifkan soft skill dan juga pelatihan kepemimpinan.

Kriteria yang Diinginkan Pengguna (stakeholders) terhadap Lulusan Prodi Manajemen Pendidikan Islam (MPI) Fakultas Tarbiyah dan Keguruan UIN Alauddin Makassar

Penelitian juga mengungkapkan tentang kriteria yang diinginkan oleh pengguna (stakeholders). Kriteria yang dimaksud adalah aspek-aspek selain yang sudah didapatkan dari hasil pertama. Untuk menjawab bagian ini, peneliti menggunakan metode wawancara baik tertulis maupun melalui via telepon.

Berdasarkan hasil penelitian didapatkan hal-hal sebagai berikut:

\section{Tanggung Jawab}

Berdasarkan hasil penelitian melalui wawancara dengan sejumlah responden, didapatkan bahwa rata-rata responden sangat mengharapkan alumni MPI yang akan bekerja di lingkungan organisasi yang diinginkan memiliki rasa tanggung jawab yang tinggi. Menurut salah seorang responden: 
"Tanggung jawab sangat penting untuk dapat menjadikan pegawai lebih bagus dalam bekerja. Dapat memberi manfaat yang besar kepada organisasi kami".

Hal sama juga dikemukakan oleh responden kedua bahwa:

"Kalau pegawai saya serius dalam bekerja, saya pasti merasa bahwa pegawai ini memiliki rasa tanggung jawab yang baik".

Demikian pula salah seorang responden yang lain yang menyatakan bahwa:

“Ada beberapa pegawai saya ketika bekerja tidak mampu memberikan pekerjaan yang baik atau memberi manfaat dari pekerjaannya. Saya selalu menganggapnya tidak bertanggung jawab".

Dari ketiga pernyataan tersebut dapat dikatakan bahwa rasa tanggung jawab ini menjadi penting mengingat bahwa tanggung jawab melahirkan pekerjaan yang bagus, pekerjaan yang memberi manfaat, dan keseriusan kerja.

\section{Produktif}

Produktif adalah sesuatu yang bisa menghasilkan atau menimbulkan keuntungan. Produktif juga bisa dikaitkan dengan suatu pekerjaan hari ini yang lebih dari kemarin atau pekerjaan esok hari lebih baik dari hari ini. Dalam pengertian yang Islami dapat dikatakan bahwa produktivitas sikap yang terus berkarya atau menghasilkan sesuatu untuk digunakan orang lain.

Berdasarkan hasil wawancara juga didapatkan bahwa produktif ini menjadi kriteria yang diharapkan beberapa stakeholders. Menurut salah seorang responden:

"Pegawai itu harus membuat sesuatu sehingga dapat memberi manfaat, kalau tidak bisa rugi kita sebagai bosnya".

Responden yang lain juga mengungkap hal yang sama, la mengemukakan bahwa:

"Saya sangat menginginkan pegawai yang mempunyai kemampuan untuk membuat sesuatu (produktif). Kalau tidak membuat yang berbeda tidak akan saya mengambilnya".

Kedua pendapat tersebut memiliki makna yang sama bahwa produktivitas seorang pekerja sangat diinginkan oleh stakholders, dengan itu organisasi akan sangat bergantung. Hal ini diingatkan juga oleh salah seorang responden yang menyatakan bahwa:

"Kalau ditanya tentang kriteria saya juga menginginkan pegawai yang bisa menghasilkan sesuatu atau membuat sesuatu yang berbeda supaya orang yang menjadi pelanggan dapat selalu menjadi pelanggan saya".

Dari beberapa pendapat di atas, dapat disimpulkan bahwa alumni yang akan terjun langsung di masyarakat juga akan menjadi rebutan apabila mereka dapat menghasilkan sesuatu yang lebih baik atau berbeda yang sudah ada. Hal tersebut mengindikasikan perlunya produktivitas. 


\section{Orientasi Target atau Hasil}

Dalam kehidupan sehari-hari sering disebutkan dua hal yaitu; orientasi hasil dengan orientasi proses. Ketika manusia belajar haruslah berorientasi proses, sehingga mereka bisa belajar dari proses itu. Sementara dalam organisasi yang menuntut adanya hasil yang baik, maka selalu diharapkan orientasi hasil, sehingga bisa dijadikan produk untuk dipasarkan.

Berdasarkan hasil penelitian mengenai hal ini, didapatkan bahwa beberapa stakeholders mengharapkan pegawai dapat berorientasi hasil. Artinya para pegawai dapat menghasilkan tidak hanya selalu berproses. Seperti yang dikemukakan oleh salah seorang responden bahwa:

"Para pegawai saya selalu dituntut untuk membuat sesuatu dengan target yang diharapkan".

Pernyataan di atas sangat beralasan mengingat pada organisasi orientasi laba pasti akan menjual sesuatu, sesuatu itu perlu dihasilkan oleh pekerjanya. Rata-rata mereka tidak terlalu memikirkan proses. Seperti yang dikemukakan oleh responden berikut ini:

"Pegawai saya bukanlah yang harus selalu belajar, mereka dibayar untuk menghasilkan. Olehnya itu mereka diberi target untuk selesai, makanya harus selalu diselesaikn dengan tepat waktu".

Dari pernyataan tersebut dapat disimpulkan bahwa para pengguna lulusan itu, sangat mengharapkan adanya hasil yang dibuat oleh pegawainya. Oleh karena itu, diharapkan selalu ada orientasi hasil bukan orientasi proses.

\section{Motivasi Tinggi}

Motivasi adalah daya penggerak utama bagi seseorang dalam bekerja atau berbuat sesuatu. Dalam teori motivasi, seseorang akan termotivasi apabila diberi rangsangan untuk mendapatkan motivasi. Rangsangan bisa berupa materi (gaji, bonus, dan lain-lain) atau juga dalam bentuk non materi seperti pelatihan atau pendidikan.

Motivasi menjadi suatu kekuatan, tenaga atau daya, atau suatu keadaan yang kompleks dan kesiapsediaan dalam diri individu untuk bergerak ke arah tujuan tertentu, baik disadari maupun tidak disadari.

Berdasarkan hasil penelitian tentang hal ini didapatkan bahwa sebagian besar stakeholders sangat menginginkan alumni yang bekerja di organisasinya dapat memiliki motivasi yang tinggi. Seperti yang diungkapkan responden berikut ini:

"Dalam bekerja dibutuhkan motivasi yang tinggi. Motivasi yang tinggi membuat pekerjaan lebih baik, tapi kalau tidak ada motivasi akan membuat pekerjaan tidak baik bahkan tidak jadi".

Pernyataan di atas menyatakan bahwa pekerjaan yang mau dilakukan butuh motivasi. Motivasi yang diharapkan perlu ditumbuhkan dengan berbagai stimulus 
seperti materi ataupun pelatihan. Hal ini sesuai dengan pernyataan responden berikut ini:

"Pegawai saya selalu saya latih supaya mereka tahu apa yang harus dilakukan supaya mereka juga termotivasi”.

Hal yang sama juga dikatakan responden berikut ini:

"Pegawai harus diberi motivasi dengan gaji yang layak sehingga dapat memiliki motivasi. Saya selalu memilih pegawai yang termotivasi yang tinggi untuk saya rekrut".

Dari beberapa hasil wawancara di atas, dapat disimpulkan bahwa alumni yang dihasilkan oleh MPI harus selalu memiliki motivasi tinggi. Motivasi juga sangat tergantung pada stimulus yang diberikan.

\section{Bekerja Keras dan Sabar}

Mengingat akan pentingnya kesuksesan dalam hidup, kerja keras merupakan kunci utama meraih kesuksesan. Sudah pasti kita memperoleh sesuatu itu bukanlah perkara gampang atau semudah membalikkan telapak tangan atau hanya meminta langsung, tapi sekali lagi harus kerja keras. Pengertian kerja keras tidak cocok diartikan secara harfiah, karena seolah bermakna bekerja dengan keras, matimatian, kurang istirahat, dan sangat lelah, Maksud kerja keras adalah bekerja dengan kemampuan yang kita punya untuk meraih sesuatu yang kita inginkan tanpa menyakiti diri sendiri dan pikiran. Bekerja keras akan membuahkan hasil jika kita sabar.

Dari pernyataan di atas, ada dua kata yang menjadi kunci dan tidak bisa dipisahkan, yaitu; kerja keras dan sabar. Kerja keras membutuhkan kesabaran dan sebaliknya kesabaran butuh kerja keras.

Berdasarkan hasil wawancara dengan sejumlah responden, diadaptakan semua responden menginginkan kriteria kerja keras dan sabar. Salah satu responden menyatakan bahwa:

"Perlu ditekankan kepada setiap alumni yang akan terjun ke masyarakat

bahwa untuk sukses butuh kerja keras dan kesabaran".

Kerja keras akan membuat orang sukses, tapi kerja keras biasanya sangat lama di sinilah dibutuhkan adanya kesabaran. Karena kesabaran membuat seseorang tidak cepat putus asa. Demikian pula dalam hal bekerja di sebuah organisasi dibutuhkan dua hal ini untuk menghasilkan sesuatu yang baik untuk organisasi. Salah seorang responden yang menguatkan pernyataan di atas, sebagai berikut:

“Pegawai itu biasanya menghadapi pekerjaan berat dan lama, makanya selalu saya katakana untuk sabar dan tetap bekerja dengan lebih keras dan baik".

Dalam menghadapi dunia yang penuh persaingan ini juga dibutuhkan kerja keras. Semakin banyaknya pencari kerja dengan lapangan pekerjaan yang semakin 
sedikit membutuhkan adanya kerja keras sekaligus kesabaran. Hal ini dikemukakan oleh responden berikut ini:

"Pencari kerja itu banyak, makanya selalu saya tekankan kepada pencari kerja bahwa saya butuh yang mau bekerja dan sabar tidak banyak menuntut".

Berdasarkan ketiga pernyataan di atas, dapat dismpulkan bahwa kerja keras dan kesabaran dibutuhkan karena, pertama, dunia kerja membutuhkan kedua hal itu, kedua, beban pekerjaan terlalu berat sekarang ini, ketiga, banyaknya persaingan di dunia kerja dewasa ini.

\section{Berpikir dan Bertindak Positif}

Berpikir positif adalah suatu energi yang akan menghasilkan pemikiranpemikiran dan sikap-sikap yang baik yang dapat membuat manusia menjadi bersemangat serta dapat melakukan hal-hal yang baik.

Berpikir positif tentu berbeda dengan bertindak positif, meskipun dalam berpikir positif biasanya akan mendorong seseorang untuk melakukan tindakan positif. Tapi perlu diketahui juga bahwa untuk mencapai sesuatu terhadap apa yang kita pikirkan tidak akan berhenti pada proses berpikir saja. Melainkan harus direalisasikan dalam tindakan yang positif pula. Bertindak positif berarti tidak merugikan orang lain atau pun organisasi di mana kita bekerja.

Hasil penelitian melalui wawancara mengenai hal ini menunjukkan bahwa sebagian besar responden juga menginginkan adanya dua hal di atas sebagai kriteria dalam menjalani dunia organisasi dewasa ini. Menurut salah seorang responden bahwa:

"Pegawai harus selalu berpikir yang positif karena dengan berpikir positif akan membuat mereka juga akan mampu berbuat yang postif".

Pernyataan di atas, menunjukkan bahwa dua kata ini juga tidak bisa dipisahkan. Artinya bahwa seseorang yang diinginkan untuk berbuat positif harus terlebih dahulu berpikir positif. Salah seorang responden menyatakan bahwa:

“Pegawai akan mampu berkreasi apabila selalu diajar untuk berpikir positif. Setelah itu dia akan berbuat positif supaya keduanya menghasilkan kreasi yang bagus".

Kreativitas sepertinya selalu berbarengan dengan berpikir positif dan berbuat positif. Jika manusia dibutuhkan kreasi yang baik maka mereka harus dibuat untuk berpikir dan berbuat positif terlebih dahulu. Demikian pernyataan di atas. Pernyataan tersebut sama dengan pernyataan responden berikut ini:

"Di dalam semua aktivitas di lingkungan kerja sangat membutuhkan berpikir dan berbuat positif, sehingga segalanya dapat berjalan dengan baik".

Dari beberapa hasil wawancara di atas, dapat disimpulkan bahwa berpikir dan berbuat positif menjadi dua kata yang selalu beriringan. Kemudian berpikir dan 


\section{A. ACHRUH, ILYAS ISMAIL, RIDWAN IDRIS}

berbuat positif juga akan dapat menumbuhkan kreativitas pekerja selanjutnya akan dapat membuat organisasi berjalan dengan baik.

\section{Menjaga Hubungan dengan Teman Sejawat}

Manusia dalam kegiatan sehari hari tidak lepas dari interaksi sesama manusia, baik yang positif dan negatif. Untuk menjaga interaksi yang positif dibutuhkan menjaga hubungan yang baik dengan teman sejawat dengan situasi yang saling menghargai dan menghormati.

Pada dasarnya semua orang ingin dihargai, tidak peduli apakah ia orang berpangkat atau tidak, orang miskin atau kaya, sesama agama atau tidak seagama, sesama suku atau tidak sesama suku, semuanya ingin dihargai secara proporsional. Namun sayangnya, banyak orang di kalangan kita yang tidak mau menghargai orang lain. Padahal menghargai orang lain bukan berarti memberikan sesuatu yang besar nilainya. Misalnya saja menghargai pendapat orang lain.

Setiap orang selalu ingin dihormati. Oleh karena itu, janganlah kita menghormati orang lain karena ia kebetulan punya pangkat atau kedudukan. Kita perlu menghormati orang lain, bila kita melihat orang lain tersebut melakukan sesuatu yang baik. Kita juga perlu menghormati orang yang lebih atau lebih maju dari kita.

Dari pernyataan di atas, dapat dikatakan bahwa dalam menjalin hubungan dengan teman sejawat perlu adanya sikap yang menghargai dan menghoramti teman sejawat. Hasil penelitian mengenai hal ini dapat dilihat bahwa sebagian besar responden juga sangat menginginkan adanya pegawai yang selalu menjaga hubungan baik dengan teman sejawat. Salah seorang responden menyatakan:

"Saya selalu berharap bahwa setiap pekerja yang ada di organisasi saya mampu bekerjasama dengan teman kerjanya”.

Kerjasama yang baik harus selalu dibarengi dengan menjaga hubungan yang baik. Tanpa hubungan yang baik akan susah mengharap kerjasama tersebut. Salah satu responden menyatakan bahwa:

“Untuk mewujudkan kerjasama pegawai saya selalu diperintahkan untuk saling menghargai dan menghormati".

Saling menghargai dan menghormati akan melahirkan saling kerjasama dan membuat setiap pekerjaan dapat terwujud dengan hasil yang lebih baik dan mampu mewujudkan organisasi yang sehat. Hal tersebut dapat dilihat pada pernyataan salah seorang responden berikut:

"Saya selalu mengaharapkan pegawai yang mampu membangun organisasi dengan baik dengan jalan saling menjaga hubungan yang baik dengan sesama pegawai".

Dari beberapa pernyataan tersebut dapat disimpulkan bahwa untuk mewujudkan kerjasama dalam membentuk organisasi yang sehat, maka perlu ditekankan adanya hubungan yang baik antara teman sejawat. Hubungan tersebut 
dibangun dengan membangun saling menghargai dan saling menghormati kemudian akan menciptakan saling kepercayaan antara anggota organisasi.

\section{PENUTUP/SIMPULAN}

Berdasarkan hasil penelitian yang telah dikemukakan sebelumnya, maka peneliti dapat menyimpulkan bahwa tingkat kepuasan pengguna (stakeholders) terhadap Iulusan MPI Fakultas Tarbiyah dan Keguruan UIN Alauddin Makassar berada pada kategori sangat tingkat. Hal ini dapat dilihat pada beberapa kategori yaitu; (1) integritas; (2) profesionalisme; (3) kemampuan bahasa Inggris; (4) penggunaan TI; (5) kemampuan berkomunikasi; (6) kerjasama tim; dan (7) pengembangan diri. Semua kategori tersebut berada pada tingkat sangat tinggi.

Kriteria yang diinginkan pengguna (stakeholders) terhadap lulusan Prodi Manajemen Pendidikan Islam (MPI) Fakultas Tarbiyah dan Keguruan UIN Alauddin Makassar adalah: (1) tanggung jawab; (2) produktif; (3) orientasi target atau hasil; (4) motivasi tinggi; (5) sabar dan bekerja keras; (6) berpikir dan bertindak positif; dan (7) menjaga hubungan dengan teman sejawat.

\section{DAFTAR PUSTAKA}

Abdi, M. I. dan A. (2013). Kiprah Lulusan Program Studi Manajemen Pendidikan Islam Pada Dunia Kerja di Kalimantan Timur. Jurnal FENOMENA, V(1)

Lavelock, C. (1988). Managing Service: Marketing, Operation and Human Resources. London: Prantice Hall Inc.

Sarjono, Y. (2007). Faktor-faktor Strategi Pelayanan Dosen dan Dampaknya Terhadap Kepuasan Mahasiswa FKIP Universitas Muhammadiyah Surakarta Tahun Akademik 2005-2006. Varidika, 9(1), 13-14.

Sopiatin. (2010). Manajemen Belajar Berbasis Kepuasan Siswa. Bogor: Ghalia Indonesia.

Srinadi. (2008). Faktor-Faktor Penentu Kepuasan Mahasiswa Terhadap Pelayanan Fakultas Sebagai Lembaga Pendidikan. Jurnal Cakrawala Pendidikan, Tahun XXVII 3, 217-231. DOI: https://doi.org/10.21831/cp.v3i3.322

Supranto. (2011). Pengukuran Tingkat Kepuasan Pelanggan: untuk Menaikan Pangsa Pasar. Jakarta: Rineka Cipta. 